Est Ag 36 (2001) 331-345

\title{
Platón y la tragedia ática
}

\section{Introducción}

Dentro de la cultura griega cada vez está teniendo más importancia el estudio de la tragedia y lo interesante es que estos estudios tratan de ponerla en relación con el discurso filosófico ${ }^{2}$. Esto choca con la antigua rivalidad entre filósofos y poetas. En el marco de este pensamiento tradicional los estudios antiguos separaban rotundamente filosofía y poesía, y aquí se incluye la tragedia, como si fueran ámbitos totalmente diferentes. Actualmente se piensa que es cada vez más necesario un estudio de la cultura griega en su totalidad. No se pueden separar la filosofía, la literatura, la historia y la ciencia. Todos los fenómenos culturales de una época son solidarios entre sí. Por eso, dentro de este planteamiento, es necesario reivindicar el estudio de la tragedia en relación con la filosofía o con el pensamiento de la época.

En esta exposición voy a referirme a las relaciones entre Platón y la tragedia; relaciones que por la información que proporciona Platón son de odio o rivalidad. Esta rivalidad brota de que los poetas, en la antigua Grecia, habí-

1. Esta comunicación fue presentada en las IX Jornadas de filosofía de la Universidad de Valladolid que se desarrollaron los días 15-17 Noviembre de 2000.

Hablamos de tragedia ática y no de tragedia griega por la estrecha relación que guarda con Atenas. Allí surgió (a finales del siglo VI), se representó y lo curioso es que los tres grandes trágicos escribieron en un período de tiempo que no llega a un siglo, unos 65 años y después, como si nada, se agotó o murió. El período va desde la primera representación de Los Persas (472) de Esquilo y las últimas Edipo en Colono de Sófocles y Las Bacantes de Eurípides en 407 a. C. Este período de representaciones corresponde en general con la época de la democracia ateniense desde las reformas de Clístenes (508) hasta la derrota por los espartanos en el Peloponeso (404). Por eso, se puede ver una relación entre la tragedia y la eclosión de la democracia y, cuando la democracia ateniense comienza a entrar en crisis, paralelamente desaparece también la tragedia.

2. NuSSBAUM, M., La fragilidad del bien. Fortuna y ética en la tragedia y la filosofía griega (=la balsa de la medusa 77), Visor, Madrid 1995. 
an sido los primeros educadores morales de los griegos y Platón disputa a los poetas este papel; lucha por ocupar su puesto.

Durante el siglo V y principios del IV a. C., los poetas eran considerados los maestros de ética más importantes. Nadie juzgaba sus obras menos consagradas a la verdad que los tratados especulativos en prosa de historiadores y filósofos. Tampoco podemos olvidar que en el siglo $\mathrm{V}$ el principal instrumento educativo era el teatro ${ }^{3}$. Con lo cual vemos que el teatro y la tragedia, en concreto, tenían una tarea educativa que cumplir y, además, era una educación popular, pues se dirigía a todos los atenienses, cosa que la filosofía no podía pretender, ya que siempre fue una instrucción minoritaria para determinados grupos de personas o escuelas. La tragedia, por el contrario, se representaba ante miles de espectadores ${ }^{4}$.

En la época anterior a Platón no había una delimitación entre los textos que buscan seriamente la verdad y los que tenían por objetivo el entretenimiento. Se distinguía entre autores de textos en prosa y poetas. No había una distinción entre pensadores éticos serios y otros pensadores menos serios. De hecho, varios de los filósofos escribieron en verso: Jenófanes, Parménides y Empédocles. Había textos de diferente tipo -poesía épica, lírica, trágica y cómica, tratados científicos e históricos en prosa y la oratoria- que enseñaban la sabiduría practica o prudencia o, al menos, que eran considerados de forma provisional como posibles fuentes de phronesis. En ningún caso el género literario indicaba que el texto en cuestión no tuviera nada importante que decir sobre el ser humano.

Aunque son innegables las rivalidades entre Platón y los trágicos, creo que existen razones para pensar que también tuvieron buenas relaciones, aunque no sean bien conocidas por nosotros. Sabemos por Diógenes Laercio (Vidas, III, 1, 2) que Platón, de joven, habría escrito alguna tragedia y que aspiraba a convertirse en autor trágico. El encuentro con Sócrates le hizo cambiar de orientación o rumbo en su vida y quemó esos primeros escritos.

Tal vez a este aprendizaje o conocimiento obedezca la similitud formal entre las tragedias y algunos diálogos de Platón. García Gual ${ }^{5}$ en la introducción a la traducción del Protágoras, nos dice que éste es uno de los diálogos

3. RODRÍGUEZ ADRADOS, F., Palabras e ideas. Estudios de filosofía griega, Ediciones clásicas, Madrid 1992, 156-166. 14.000 .

4. El teatro de Dionisos reunía a más de 20.000 espectadores y el de Epidauro a

5. Platón, Diálogos I. Apología, Critón, Eutifrón, Ion, Lisis, Cármides, Hipias Menor, Hipias Mayor, Laques, Protágoras (=BCG 37), Gredos, Madrid 1981, 494-499. Véase también NUSSBAUM, M., La fragilidad del bien, 178-183. 
más animados, más teatrales y brillantes, que acreditaría a Platón como escritor dramático. El Protágoras muestra una interacción dialéctica, y al igual que la tragedia, expone una comunicación y un debate moral. Platón escogió un género apropiado para exponer la filosofía: el diálogo, que guarda bastante similitud con la técnica de la tragedia, así como la técnica de discusión de sus enemigos los sofistas. Tampoco extraña que en la Atenas del siglo V se forje un teatro lleno de discusiones dialécticas, ya que los debates públicos surgían por todas partes y se animaba a cada ciudadano a participar o, cuando menos, a convertirse en juez activo y crítico.

En este teatro antitrágico platónico se expresa el compromiso del filósofo con el intelecto como fuente de verdad. Al escribir filosofía con forma dramática, Platón se dirige al lector para que participe activamente en la búsqueda de la verdad. El estilo de Platón no es neutral con respecto al contenido de su reflexión; antes al contrario, está estrechamente vinculado a una determinada concepción de la racionalidad humana. Sin embargo, los diálogos no son tragedias. Los diálogos son una especie de teatro y están en deuda con los modelos de la tragedia, pero son también un teatro creado para sustituir a la tragedia como paradigma de enseñanza moral. En la tragedia se presentan personajes implicados en una acción de enorme importancia para sus vidas y dirigiéndose por los elementos no intelectuales del alma (pasiones, deseos, sentimientos). El diálogo platónico usa un tono seco y abstracto, excluye positivamente la excitación de pasiones y sentimientos, dirigiéndose exclusivamente a nuestras facultades racionales. Platón piensa que aunque la obra tenga por fin enseñar la sabiduría práctica se debe dirigir al intelecto, porque el lenguaje dirigido al sentimiento y a la pasión puede distraer a la razón en la búsqueda de la verdad ${ }^{6}$.

La verdad que nos trasmite la tragedia es distinta del saber filosófico. La tragedia, para transmitir la sabiduría acerca de los dioses u hombres, usa representaciones y no conceptos o abstracciones, pone en escena los acontecimientos humanos. Las tragedias se apoyan en las impresiones, en el pathos, son la representación patética de la sabiduría, mientras que las obras filosóficas usan una forma noética de sabiduría. En la tragedia también hay momentos conceptuales pero son los menos; lo propio de la tragedia es representar imágenes en acción.

La crisis de la aristocracia y la tiranía dieron lugar a la democracia donde la tragedia tuvo su mayor esplendor; la crisis de la democracia dará origen a

6. NUSSBAUM, M., La fragilidad del bien, 186. 
un nuevo modelo de educación (el socrático-platónico), que se opone a la tragedia y a la sofística. Se puede ver que existen muchas conexiones entre la sofística y la tragedia, especialmente en Eurípides y también alguna influencia en Sófocles. Por eso, tal vez la crítica de Platón a la tragedia que analizaremos no sea tanto en cuanto forma de teatro sino porque, muchas veces, trasmitía la educación o mensaje sofístico que él no consideraba adecuado para su ciudad ideal. Las tragedias trataban de difundir la cultura de las clases populares. Platón, en este sentido, no lucha tanto contra la tragedia como contra aquel tipo de cultura que las tragedias representaban. Platón, al tiempo que propone un nuevo tipo de ciudad, explicará que parte del fracaso de la democracia ateniense era consecuencia de la educación trasmitida por los poetas. El ataque de Platón a la tragedia está inspirado en la profunda desilusión por la decadencia de la Atenas que conoce. La ciudad ideal que propone precisa una nueva educación que garantice la presencia de personas moderadas y equilibradas.

Veamos las dos críticas fundamentales de Platón a la tragedia.

\section{Crítica desde la teoría del conocimiento: la mimesis}

Una de las razones por las que Platón condena el arte y la tragedia en particular es, desde su teoría del conocimiento, porque pertenece al nivel inferior de conocimiento. En la imagen de la línea cortada (República VI, 509 d511c) y en el mito de la caverna (República VII, 514b-516b) nos habla de cuatro niveles de conocer: $1^{\circ}$ ) El de las Formas o Ideas. $2^{\circ}$ ) El de los objetos matemáticos y geométricos. $3^{\circ}$ ) $\mathrm{El}$ de los objetos sensibles, el mundo exterior. $4^{\circ}$ ) El de las imágenes, las sombras y las representaciones. En este nivel inferior es donde tiene cabida la tragedia.

Las tragedias son condenadas por pertenecer a este cuarto nivel del conocimiento; son imitaciones; por lo tanto no son verdaderas. Para Platón todo el mundo del arte es una imitación de la naturaleza. La naturaleza es una imịtación o sombra del mundo perfecto de las Ideas. El arte es una imitación de imitaciones; por lo tanto representa el conocimiento más alejado de la ver$\mathrm{dad}^{7}$.

7. NIETZSCHE, F., El nacimiento de la tragedia o Grecia y el pesimismo (=Clásicos 456), Alianza Editorial, Madrid 1988, (14), 120. "El reproche capital que Platón había de hacer al arte anterior (el de ser imitación de una imagen aparente), es decir, el pertenecer a una esfera inferior incluso al mundo empírico." 
Como vemos, Platón rechaza la tragedia porque es mimesis8; es decir, la tragedia no es realidad sino representación de otras cosas. Conviene recordar que Platón está entendiendo el concepto de mimesis en un doble sentido: en un sentido estético, profundo, en cuanto encarnación; pero también en un sentido más cotidiano, en el horizonte de la ficción, como imitación de caracteres buenos o malos (este último fue el sentido más polémico en Platón).

La mimesis originalmente no es una imagen o representación sino una encarnación, un doble de una realidad del pasado o de otro tiempo. La mimesis hace presente una realidad de otro mundo, la actualiza, como una acción ritual. La mimesis no es una encarnación cualquiera; en ella, dos mundos distintos y distantes se ponen en contacto y lo inaccesible se hace presente 9 . La mimesis no identifica dos motivos que necesariamente se parecen, sino, precisamente, dos motivos o realidades que pertenecen a ámbitos radicalmente diferentes, el mundo de los dioses y el de los hombres. Aquel que participa en la acción ritual, en la mimesis, está representando a una divinidad, un héroe o un animal, pero esa representación es una verdadera encarnación.

Según este concepto original de mimesis, la tragedia es la encarnación de lo divino en el tiempo mediante la representación. Las tragedias toman las tradiciones de los dioses y mitos de Homero ${ }^{10}$ y representan esas historias en la vida de aquel tiempo a veces criticando la religión o a los dioses, pero lo que fundamentalmente hacen es una adaptación de las antiguas mitologías de la religión arcaica (de la vida de los dioses, demonios, héroes) a la vida de la ciudad. Muestran el paso de una religión cósmico-natural a la religión cívica, la religión de la polis;por eso son necesarias adaptaciones e interpretaciones.

La tragedia presenta el choque entre el mundo cósmico (personajes forzados a actuar porque los dioses lo han dispuesto y no pueden escapar de su destino) y la vida de la ciudad regulada por leyes hechas por los hombres, que son convencionales y variables. El hombre, frente a este orden en el universo que se rige por las leyes naturales incomprensibles, se encuentra desorienta-

8. BOZAL, V., Mimesis: las imágenes y las cosas, Visor, Madrid 1974, 65-95. La mimesis no es un concepto inventado por Platón, posee una larga tradición en el mundo griego, en el culto y las manifestaciones artísticas ligadas a él, en el teatro y la lírica, también en las artes plásticas.

9. La mimesis significa también el cambio de personalidad que se experimentaba en ciertos rituales donde los fieles sentían que se encarnaban en ellos seres de naturaleza no humana (divina o animal) o héroes de otro tiempo.

10. NiETZSCHE, F., El nacimiento de la tragedia, (10) 98-99. Aquí claramente se nos dice que con la poesía trágica los mitos homéricos vuelven a nacer con figura distinta, como que representan una nueva cultura; la homérica ha sido vencida. 
do como si su vida fuera inútil. Este es el hombre que presentan las tragedias, un hombre escindido entre el mundo de la polis, donde se siente autónomo y protagonista, y un mundo natural que se le escapa e impone. El hombre experimenta a un tiempo la libertad y la confianza en sus posibilidades, pero también su limitación y dependencia.

Del significado de la mimesis original, como encarnación de lo divino, se pasó a la mimesis teatral, la mimesis ficticia que se produce en el ámbito de la ficción. Ya no estamos ante la divinidad encarnada en los actuantes, estamos ante un espectáculo en el cual un actor finge ser encarnación de la divinidad. $\mathrm{El}$ actor tiene que convertir esa ilusión en una presencia convincente, real. Sólo así será posible crear en el escenario una mimesis plena, que conmocione la sensibilidad del espectador y produzca en él los efectos de evidencia, purificación, etc., que la acción sacral había logrado. El teatro engaña al espectador; en eso consiste su grandeza, también su interés político, puesto que propondrá como mimesis lo que no es sino simulación.

Platón se va a ocupar de la mimesis, especialmente desde la perspectiva de la educación y la formación. De este modo, considera la mimesis como un factor negativo en la educación. Su hostilidad contra las artes miméticas (las interpretaciones y las representaciones) la enuncia enla República 395d: "Los actos de mimesis, si se persevera en ellos desde la niñez en adelante, se atrincheran en nuestros hábitos y el carácter del cuerpo, de la voz y del estado mental por igual". Uno llega a parecerse a lo que hace o incluso a lo que ve que se hace. Por lo tanto, los actos de mimesis no pueden ser buenos para la educación de los jóvenes en la ciudad ordenada que nos describe Platón, pues sería una educación fundada en las apariencias o en la fantasía. Platón hace una crítica a los contenidos de la poesía tradicional y sus efectos negativos sobre las costumbres. Piensa que la poesía echa a perder el valor, el equilibrio, el dominio de sí y la justicia, sobre todo si a los niños, en la temprana infancia, momento en que tienen que formar su carácter, se les refieren estos cuentos, pues pueden influir negativamente en la formación de los futuros guardianes y ciudadanos ${ }^{11}$.

11. KAUFMANN, W., Tragedia y Filosofía (=serie mayor 36), Seix Barral, BarcelonaCaracas-México 1978, 41-42. Platón, en el libro III de la República, cita frases de Homero cuyo sonido puede hacernos temblar; habría que censurarlas al igual que muchas lamentaciones de los héroes. Aunque no menciona al respecto ninguna tragedia, podía haberse referido perfectamente al Filoctetes o Las traquinias de Sófocles, como ejemplos extremos, ya que Filoctetes y Heracles lloran y se quejan de sus sufrimientos. Aunque aquí Platón no menciona a los poetas trágicos es evidente que se refiere a ellos. Siguiendo este principio Platón prohibiría la mayoría de las tragedias: Antígona y Electra de Sófocles, Medea, Hipólito y las Troyanas de Eurípides. 
Platón critica la tragedia por la influencia negativa que podía tener en el comportamiento de las gentes si tendían a imitar las representaciones; pero sobretodo porque excitaba o ponía en movimiento la parte irracional del alma. La poesía, de este modo, cultiva la parte inferior del alma y hace que lo que tenía que ser gobernado por nosotros, la parte irascible del alma, sea la que nos dirija. En el libro X de la República Platón añade que la respuesta emocional a la poesía trágica refuerza de hecho los elementos no intelectuales del alma, convirtiéndolos en fuente de distracción y trastorno del intelecto. "Riega" nuestras pasiones, cuando debería "secarlas" (606 d). Se critica la poesía por "alimentar" las partes irracionales del alma con sus contenidos moralmente dudosos y su estilo que excita las pasiones. Por lo tanto, la condena de la mimesis es porque impide que alcancemos la verdad, al hacernos ver que la apariencia es verdad. Rechazando la idea de que el poeta ilumina la verdad, opone la deficiencia cognoscitiva de aquél a la sabiduría del filósofo. En la República el único testigo y juez moral fiable es el intelecto, los elementos no intelectuales no aportan valor cognoscitivo. Los apetitos son fuerzas brutas. Tales fuerzas ineducables no pueden guiarnos hacia el bien. El intelecto debe ser separado y permanecer puro y claro, en sí mismo y por sí mismo 12

El libro X de la República expone nuevamente la crítica al poeta trágico, al pintor y todos los que cultivan las artes imitativas; los dos son imitadores que nada entienden del ser, sólo de las apariencias. "Da la impresión de que todas las obras (tragedias) de esa índole son la perdición del espíritu de quienes las escuchan..." (595 b). Para Platón, todos los poetas, comenzando por Homero, son imitadores de imágenes de la excelencia y de las otras cosas que crean, sin tener nunca acceso a la verdad (600 e). El creador de imágenes, el imitador, no está versado en lo que es sino en lo que parece $(601 \mathrm{c})$. Platón dirige sus acusaciones contra los poetas por crear únicamente lo que produce placer y obtener la aprobación de las masas ignorantes. La imitación no puede tomarse en serio; $y$ tanto los que hacen poesía trágica como épica o dramática son imitadores y deben ser rechazados (602 b). Se condena al poeta trági-

12. NuSSBAUM, M., La fragilidad del bien, 284-286. Platón, en el Fedro, tiene otra opinión: afirma que tanto la manía como la sophrosyne pueden educar a las personas. La colaboración de nuestros elementos no intelectuales es necesaria para alcanzar aquello a lo que aspira el intelecto. Platón aquí parece admitir que el plan ascético de la República, que priva de la pasión y del alimento de la poesía dramática y del amor a los seres cercanos y a la familia, puede paralizar la personalidad, incluso si ésta es purificada. En el Fedro se reivindican los elementos no intelectuales pues desempeñan una importante función de guía en la búsqueda del saber. 
co por ser creador de fantasmas, ya que no sólo engaña sino que convive con la apariencia y la presenta como verdad.

Platón concluye diciendo que la razón nos obliga a desterrar la poesía de nuestra ciudad. El artista imitativo engaña y al hacerlo impide que nos elevemos a la verdad, pues nos da como verdadera su familiaridad con la apariencia. La mimesis obstaculiza el ascenso, al hacer ver que la apariencia es la verdad, nos retiene en esos fantasmas que son las imágenes de los objetos concretos, pretendiendo que la belleza se encuentre en la representación de la cosa bella, singular. Esta crítica contra el pintor y el poeta va dirigida al poeta trágico y, más en concreto, a Homero, el mayor de los poetas y el primero de los trágicos. Sólo tienen cabida en la ciudad los himnos a los dioses y los panegíricos de hombres ilustres. $\mathrm{Si}$, por el contrario, se permite la lírica o la épica, reinarán en la ciudad el placer y el dolor en lugar de la ley y la norma (607 a).

Según Platón se debe escoger entre dos tipos de vida: la vida de las pasiones o emociones que desarrolla la poesía, o una vida que cultiva la virtud y la felicidad y que está sometida a la razón. Esta solución platónica en realidad es más austeridad que felicidad, al haber eliminado las pasiones y sentimientos. Platón se convierte en un profeta de la austeridad y del puritanismo. La razón para cultivar la excelencia y la justicia y no el honor y las riquezas es que el alma es inmortal. Según Kaufmann, los poetas trágicos son también rechazados, porque muestran, aunque no sea ése su intento, que muchas veces los hombres justos se llevan la peor parte ${ }^{13}$. Con estas ideas Platón prohibiría muchas de las obras de Sófocles y de Eurípides, de quienes fue contemporáneo, donde se representa una visión más realista de la vida que la platónica, pues es evidente que a los justos no siempre les va bien en la vida; a veces, parece todo lo contrario. Por otra parte, Platón, que rechaza la poesía por ser mimesis, recurre constantemente a los mitos (que también pertenecen al mundo de las sombras o representaciones) para dar razón de la justicia. La República, en concreto, concluye con el mito de Er; Platón habla de un dios supremo que adjudica recompensas o castigos después de la muerte ${ }^{14}$.

13. En la República 392 b: "Los poetas y narradores hablan mal acerca de los hombres en temas importantes, al decir que hay muchos injustos felices y en cambio justos desdichados, y que cometer injusticias de provecho si pasa inadvertido, en tanto la justicia es un bien ajeno para el justo, y lo propio de esto su perjuicio..."

14. KaUfmanN, W., Tragedia y filosofia, 55. De todos modos, en otros diálogos (Apología, Crítón) Platón había dicho que ningún mal puede perturbar al hombre justo porque la virtud es su propia recompensa, ya que crea en él una serena confianza en sí mismo, una felicidad heroica que triunfa sobre la calumnia, la persecución y la muerte. Es el mismo ejemplo de Sócrates que no sucumbe ante las amenazas, acusaciones injustas y la 
La actitud de Platón en relación a la tragedia o artes imitativas en las Leyes ${ }^{15}$ prácticamente es la misma que en la República.

Hemos de decir que esta crítica platónica a la tragedia no es muy acertada, pues las tragedias son fieles a una tradición profundamente griega, en cuanto son una llamada a la mesura humana, como lo eran los famosos preceptos délficos. Las tragedias asumían los preceptos délficos de "nada en demasía" y "conócete a ti mismo", propiciando que los hombres alcanzasen la sophrosyne. Aunque en las tragedias (especialmente de Sófocles) se mostraban acciones inmoderadas, donde los héroes muchas veces se dejaban llevar por la hybris, el mensaje final era, precisamente, que aquellos héroes que intentaban escapar de su condición dejándose llevar por la intemperancia acababan mal. Aunque Sófocles presenta un tipo de héroe que llega a los extremos más opuestos, quería trasmitir a la audiencia un mensaje de moderación y sensatez ${ }^{16}$. Las tragedias trataban de enseñar la sensatez a los que no la poseen; ahora bien, lo hacen por medio de las representaciones. Las personas después de ver las diferentes representaciones teatrales y la vida de los personajes debían sacar la conclusión de que ellos debían seguir una vida moderada y equilibrada. Por lo tanto, las tragedias se apropian de los preceptos délficos y son portadoras de una cultura de la proporción, la medida y la serenidad.

Algo semejante es lo que quiere decir Aristóteles con la catarsis. El hecho de que el espectador vea emociones violentas o ciertos comportamientos reprochables de los héroes no quiere decir que tenga que imitarlos, sino que, por el contrario, podría aprender el dominio de sí. Aristóteles ${ }^{17}$ piensa

misma muerte. Esta es una respuesta diferente a la que dan los poetas al problema del sufrimiento. Una invitación a transformarnos a nosotros mismos en obras de arte que contrarresten la injusticia humana y el sufrimiento natural.

15. KAUfmann, W., Tragedia y filosofía, 57-63. Su punto de vista acerca de la poesía permaneció invariable en cuanto hubo destruido sus poemas de juventud para dedicarse a la filosofía. En las Leyes Platón no cambió su manera de pensar sobre los poetas trágicos (817). En los libros II y VII de las Leyes (655 a ss. y 812 c ss.) pone de relieve el carácter mimético de la danza y la música; señala también su función educativa.

16. Este es un mensaje recurrente en muchas de sus tragedias: Ayax (v. 500ss.), Antígona (v.382 y 1246-1352) Edipo Rey (v. 589), Electra (v.307), Filoctetes (vv. 304 y 1259) Traquinias (v. 435).

17. NussBaUm, M., La fragilidad del bien, 469. Aristóteles se distancia de Platón y recuperará la tragedia o los valores que la tragedia representa, intentará dar la importancia que se merecen a las pasiones. Podemos afirmar que sin el material proporcionado por las tragedias eurípideas, Aristóteles no habría podido analizar con tanta profundidad los principios interiores de la acción humana: la voluntad, la libertad, la reflexión y la decisión. En la Poética y en la exposición sobre la educación de los jóvenes ciudadanos, otorga a la tragedia un lugar de honor, atribuyéndole valor tanto motivacional como cognoscitivo. 
que las representaciones trágicas pueden servir como liberación o catarsis a ciertas tensiones; las personas después de ver ciertas representaciones se liberan de ciertos temores.

Platón, aunque se siente a gusto con Homero ${ }^{18}$, Hesíodo -ya que los cita constantemente- y los líricos, tiene un enfrentamiento con los trágicos y la mayor prueba es que los ignora ${ }^{19}$. No hay una sola ocasión en que cite las obras de Sófocles, sólo habla de él dos veces en sus diálogos y siempre de una manera accidental. Si Platón considera que la tragedia es perniciosa y que los poetas trágicos tienen que ser excluidos de la ciudad ejemplar, lo lógico es que se hubiera dignado considerar las mejores tragedias de su época, la mayoría de ellas escritas y representadas durante su vida. Pues, ¿qué pensaríamos nosotros de un escritor que hubiese rechazado a los filósofos sin considerar a Platón ni a Sócrates? Aunque muchas de las críticas de Platón a la tragedia y a Homero fuesen aplicables a la mayoría de los poetas trágicos del siglo IV, fallan por no tomar en consideración a los tres grandes. Debemos concluir diciendo que si Platón no crítica directamente a Sófocles ni una sola vez, es que no tiene motivos suficientes; o pudiera ser que no se atreviera por miedo a recibir el rechazo de la gente. Creemos que este silencio de las grandes obras trágicas es claramente deliberado ${ }^{20}$.

Es posible, que esta critica de Platón fuera acertada en relación con los epígonos trágicos del siglo IV que, al igual que algunas de las obras de Eurípides, ponían en escena personajes representando una serie de caracteres buenos o malos que se podían proponer como imitación. Pero esta critica difícilmente puede abarcar a los grandes trágicos, ya que sus representaciones trataban de poner en relación el mundo de los dioses y el mundo de los hombres. La mimesis consistía en una encarnación o actualización del mundo de los dioses en la vida de la polis.

18. En el fondo Platón crítica o cuestiona a Homero como educador de la Hélade. Pues los mitos y leyendas tanto de Hesíodo como de Homero muchas veces son malos ejemplos y eso no es bueno para la educación de los niños. Pues los niños no distinguen entre lo alegórico y lo no alegórico, y las impresiones de esa edad no son fáciles de borrar ni de cambiar.

19. Platón usa esta misma técnica de no citar directamente para atacar a Demócrito y a los sofistas.

20. KAUfMANn, W., Tragedia y filosofía, 535: "Sócrates atacó simplemente la extendida noción de considerar a los poetas como los mejores de entre los que saben." 


\section{Crítica desde la religiosidad}

Platón también critica la tragedia o a los poetas por su concepción sobre los dioses o lo divino. Kaufmann ${ }^{21}$ resume los tres aspectos por los cuales Platón criticó este discurso poético: 1) dios es responsable de lo bueno sólo, nunca del mal;2) dios nunca cambia, y 3) dios nunca miente o engaña.

Estas críticas a la religión aparecen en la República II y las voy a enumerar de una manera breve:

379 c: "Dado que dios es bueno, no podría ser causa de todo, como dice la mayoría de la gente..."

379 e: "Ni admitiremos tampoco que se diga que Zeus es para nosotros dispensador de bienes y de males."

380 b: "Declarando que el dios ha producido cosas justas y buenas [...] que el autor de infortunios es el dios, no hemos de permitírselo al poeta [...] Dios que es bueno, se ha convertido en causante de males para alguien, debemos oponernos por todos los medios..."

380 c: "Dios no es causa de todas las cosas, sino sólo de las buenas."

382 e: "El dios es absolutamente simple y veraz tanto en sus hechos como en sus palabras, y él mismo no se transforma ni engaña a los demás por medio de una aparición..."

Platón cree que no ha de permitirse que los poetas presenten a los dioses haciendo el mal o transformándose: lo excelente no es susceptible de modificación; tampoco mintiendo, aunque considera que las mentiras o falsedades pueden ser útiles para los hombres. Reconoce, por ejemplo, que es adecuado que los gobernantes mientan para beneficio del Estado (389 c).

Como puede apreciarse, uno de los problemas que tiene Platón con la tragedia es el concepto de religiosidad que presenta, totalmente diferente del suyo. La tragedia, desde el punto de vista religioso, es una continuación de la religión olímpico-homérica adaptada a la ciudad; también de algún modo está en relación con la religiosidad popular del culto a Dionisos. El elemento básico de esta religión mistérica es la transformación. El hombre, al participar de este culto por medio del éxtasis, se convertía en un hombre distinto del que era cuando se hallaba envuelto en el ajetreo del mundo. De este modo, se anu-

21. KaUfMANN, W., Tragedia y filosofía, 37. 
laba la diferencia o separación entre la vida de los dioses y la vida de los hombres $^{22}$.

La concepción de los dioses en Homero y después en los trágicos (Esquilo y Sófocles especialmente, pues en Eurípides se da una especie de secularización) es que no siempre son justos en el sentido humano, pues muchas veces son los que empujan a los hombres a hacer el mal. Por ejemplo, Agamenón es movido por dios a sacrificar a su hija; Orestes, por las Erinias, a vengar la muerte de su padre y matar a su madre Clitemestra, etc.

Platón, como vemos en la República, defiende que dios que es el Bien, sólo puede hacer el bien, practicar la justicia, ser justo. Conviene recordar que en el Antiguo Testamento se encuentran opiniones contrarias a esta concepción platónica de lo divino. Se dice, por ejemplo, que "Yahvé da la muerte y la vida, la pobreza y la riqueza, humilla y enaltece..." $(1 \mathrm{~S} 2,6-8)^{23}$. Se presentaba una conexión entre pecado y sufrimiento. A veces, Dios mandaba el sufrimiento como castigo por el pecado, lo cual no era más que una forma de explicar el sufrimiento en Israel. Los profetas intentaron cambiar esta imagen de Yahvé como el que da "la muerte y la vida". Ellos creen que Dios nada tiene que ver con el sufrimiento a no ser por culpa de la libertad y pecaminosidad del hombre. Según esta explicación, el sufrimiento es consecuencia del pecado. Pero el problema más grande para Israel consiste en explicar lo incomprensible del sufrimiento de los justos y piadosos, por ejemplo, el sufrimiento de Job. Al final siempre se impone la idea de que Dios es autor del bien y enemigo del mal; existe cierta seguridad de que el bien acabará por triunfar; ésta es al menos la fe del pueblo de Israel. Ellos tienen una fe en Dios pero no lo comprenden totalmente, es un Dios impenetrable, misterioso. No obstante, no dudan, en el fondo, de su bondad.

Platón aboga por la moralización de lo divino, por presentar una concepción de lo divino más racional. Frente a la idea de presentar a Dios como responsable tanto del bien como del mal, creador de la luz y de la tinieblas, dador de la dicha y la desgracia, Platón considera que de Dios sólo proviene el bien. El problema es buscar o explicar de dónde procede lo malo (379 c). Platón critica a Esquilo quien dice que Dios siembra culpabilidad en los hombres cuando quiere destruir una dinastía por completo ${ }^{24}$ (380 a). En este sen-

22. LESKY, A., La tragedia griega, Labor, Barcelona4 1973, 66. Dionisos y el mito, la fascinación del éxtasis y la fuerza del logos que penetra la esencia de las cosas, han concentrado un pacto irreiterable con la tragedia.

23. Hay otros textos semejantes: Am. 3,6; Lm 3,38: Is 45,5ss; Jb 2,10; Ez. 18,2ss.

24. LESKY, A., La tragedia griega, 86. "Los dioses no castigan al culpable más que en sus hijos y los hijos de sus hijos." 
tido Platón se rebela contra muchas de las afirmaciones de las tragedias. Por ejemplo, la afirmación constante: "Nada hay en esto que no sea de Zeus"; pues de dios sólo puede provenir lo bueno.

Los trágicos, frente a Platón, representarían una concepción de la religiosidad más antigua o tradicional. El fragmento 102 DK de Heráclito nos puede ayudar a explicar la religiosidad que reflejan las tragedias: "Los hombres encuentran algunas cosas injustas y otras justas; pero a los ojos de Dios todas cosas son hermosas, buenas y justas". El hombre, por mucho que quiera o intente, no puede llegar a conocer la mente de los dioses y hay cosas que le parecen injustas pero es que él no lo comprende; su mente es limitada. Muchas de las tragedias de Sófocles ${ }^{25}$ nos vienen a decir, en contra de Platón, que los dioses están muy por encima del hombre y de su pensamiento. No podemos antropologizar a los dioses ni hacerlos a nuestra imagen y semejanza; muchas cosas que consideramos como injustas en realidad es porque no alcanzamos a comprender, ya que no podemos ir más allá de nuestras cavilaciones. Con esto no pretendo justificar lo injustificable o dar razón de todo, sino únicamente reconocer la limitación del hombre y las muchas cosas que no alcanza a comprender. Precisamente es una llamada a que los hombres ajusten su vida a su condición y estaría en relación con la sentencia délfica: "reconoce lo que eres". El hombre tiene que reconocer los límites de su esencia.

Sófocles renunciaría a comprender la marcha de lo divino a través del mundo. El héroe sofocleo vive esa disonancia entre su deseo de individuación, de ser por sí mismo, y el mundo de los dioses que todo lo envuelve y de quien depende. El hombre vive una situación de paso entre dos mundos; por un lado, está llamado a vivir su vida al margen de los dioses, pero, por otro lado, no es capaz de vivir sin los dioses y sin la ciudad. Esta es su tragedia; está llamado a construir su vida por sí mismo, pero al mismo tiempo no puede construir su identidad sin la ciudad y sin los dioses.

Las tragedias nos presentan una concepción pesimista o realista de la condición humana, cómo ciertas fuerzas irracionales (ate, mania, demon) actúan sin que podamos llegarlo a entender, acciones que se nos imponen y no podemos evitar. Nos presentan también el dolor y el sufrimiento connatu-

25. LESKY, A., La tragedia griega, 124: "Todo lo que existe y todo lo que sucede es divino; Zeus está en este mundo con todos los otros dioses, pero el sentido de su obrar no le es revelado al hombre. No es adecuado para el hombre querer escudriñar los misterios del gobierno de los dioses ni tampoco rebelarse contra la terrible gravedad con que se deja a menudo sentir." 
rales a la existencia humana y la idea de que el dolor es fuente de conocimiento, sabiduría o aprendizaje (Esquilo ${ }^{26}$ y Sófocles ${ }^{27}$ ). Los griegos no se preguntan por la causa del sufrimiento, es un hecho; parece que lo importante es la actitud a adoptar frente al mismo, y vemos que es la resignación, someterse al destino previsto por los dioses. Estos héroes no se rebelan contra el sufrimiento como se puede ver en el libro de Job.

Platón, en cambio, nos presenta un dios más racional; trata de dar una explicación dentro de un orden. La tragedia nos desvela un mundo donde no todo es orden sino donde hay fuerzas irracionales que se escapan a la razón o, al menos, que nosotros no llegamos a explicar ni a controlar. El hombre tampoco es la persona equilibrada que se dirige por la parte superior del alma (razón) sino que, a veces, las pasiones y los sentimientos son más fuertes o dirigen el actuar humano (Medea, v. 1087).

Pero la pregunta sigue en pie ¿quién causa el mal? ¿por qué existe el sufrimiento? Sabemos que determinados sufrimientos pueden enriquecer positivamente al hombre y sus facultades humanas e incluso pueden hacer madurar su personalidad. Además soportar ciertas dosis de dolor hace al hombre más sensible para los demás, abierto al amor y a la ternura, siendo consciente de su vulnerabilidad y la limitación. La solución, si la hay, no es fácil. La tragedia viene a decirnos que el mal está ahí. Platón que el mal es fruto de la ignorancia o del olvido. El dualismo hablará de dos principios: uno que causa el bien y otro que causa el mal. Cualquier explicación nos parece insuficiente.

Parece que no hay solución al problema del mal. La tragedia vendría a decirnos que, si uno es creyente, no puede pedir aclaración de todo; explicarlo todo, sería exigir unos dioses al modo humano. Por eso, desde esta concepción de la tragedia hemos de decir que la idea de un dios asequible a la razón que nos presenta Platón, no es dios. La tragedia presentaría unos dioses que, a veces, son incomprensibles para el hombre. La razón humana no puede abarcar del todo a los dioses ocultos, misteriosos, insondables. La creencia en los dioses exige que le hombre les acepte, aunque no tenga razones para comprenderles totalmente.

Los griegos concebían un mundo lleno de dioses, de una manera que nosotros no podemos ni imaginar. Mientras nosotros muchas veces racionali-

26. Agamenón, v. 176.

27. Las Traquinias, vv. 1-3. Edipo Rey, vv. 1529-1530. 
zamos sobre la condición humana, la tragedia explica la incapacidad del hombre para conocer su futuro y realizar su presente. Por encima del hombre está el mundo de los dioses y ellos son los que dirigen el mundo y la vida, aunque sea incomprensible para los mortales.

Tal vez esta sea la razón por lo que incluso Eurípides, que participa de la mentalidad sofística y de la racionalización de la época, al final de su vida escriba las Bacantes, tragedia en la que se vuelve al mundo religioso. Es posible que Eurípides estuviera cansado del exceso de racionalización o se diera cuenta que esa era una de las causas de la decadencia de Atenas. La tragedia es la prueba de que nunca se perdió el sentido de lo divino en Grecia. La tragedia ática vendría a frenar la fuerte ola de racionalización del siglo $\mathrm{V}$, al poner en escena otras fuerzas irracionales que están siempre presentes en el mundo.

\section{Conclusión:}

Debemos aprender de Sócrates y de Sófocles, sin intentar lo que hizo Platón: fundir sus genios de una manera que nos permitiera prescindir de los poetas trágicos. Nuestra fe está en el pluralismo, en la suma y no en la resta. Las obras de los grandes trágicos nos hacen sensibles a los sufrimientos de nuestros vecinos y nos llevan a poner en tela de juicio tanto las opiniones recibidas como las propias. Los poetas trágicos son los rivales del platonismo que está muerto. Ahora hemos descubierto que la filosofía, tal como la veía Platón, era una ilusión, mientras que los poetas trágicos nos muestran la realidad de la vida. Nos recuerdan que las ideas van acompañadas de seres humanos que son limitados y que a veces chocan entre sí. La filosofía no puede vivir sin la tragedia. Nadie puede suplantar la tragedia, la razón no puede ni debe ahogar a la vida. El espíritu socrático, que mata la tragedia, es el que ahora debe morir para recuperar la vida. Nietzsche nos dice que es necesario matar el espíritu socrático, ya que matar la tragedia es separarnos de la madre tierra, de la verdadera vida. 